\title{
Focus on Form: A Critical Review
}

\section{Rod Ellis}

\section{University of Auckland and Shanghai International Studies University}

\begin{abstract}
'Focus-on form' (FonF) is a central construct in task-based language teaching. The term was first introduced by Long $(1988 ; 1991)$ to refer to an approach where learners' attention is attracted to linguistic forms as they engage in the performance of tasks. It contrasts with a structure-based approach - 'Focus-on-forms' (FonFs) - where specific linguistic forms are taught directly and explicitly. However, there is perhaps no construct in SLA that has proved so malleable and shifted in meaning so much. This review article begins by considering how Long's original definition of it has stretched over time and then offers an updated definition of the construct based on the view that the term is best used to refer to specific kinds of 'activities' or 'procedures' rather than to an 'approach'. A classification of different types of focus on form activities/ procedures is then presented. There follows a discussion of focuson-form from a psycholinguistic and discoursal perspective along with a review of research relevant to these perspectives. The article addresses a number of criticisms that have been levelled against focus-on-form with special consideration paid to how focus-on-form can be utilized in instructional contexts where more traditional (i.e., FonFs) approaches have been the norm.
\end{abstract}

\section{Introduction}

Applied Linguistics is a relatively new academic discipline and, as such, is characterized by the invention of a large number of technical terms to label constructs of importance to the field. These constructs are, however, not stable, evolving as a result of research and accompanying theory development. However, even though the constructs themselves are not stable, the original labels stick. The result is uncertainty as to the reference of a specific term. There is perhaps no term in Applied Linguistics that this applies to more than 'focus on form', whose meaning has morphed quite remarkably since it was first introduced.

In this article I will use the terms 'focus on form', 'focus on forms', 'FonF', 'and 'FonFs'. I will use the terms FonF and FonFs to refer to general approaches to teaching and 'focus on form' and 'focus on forms' to refer to specific instructional procedures.

I will begin by considering the early use of 'focus on form' by Michael Long and how his definition of it has stretched over time. I will then offer my own definition of the construct, at the same time presenting a classification of different types of focus on form. In the next two sections I will examine the psycholinguistic and discoursal dimensions of focus on form. This will prepare the way for a review of the research that has investigated different realizations of focus on form. Next I take a look at the criticisms that have been levelled against focus on form followed by a review of studies that have compared FonF and FonFs. Finally I draw the various threads of this review together in the conclusion section and argue that little is to be gained by disputing the relative merits of FonF and FonFs as what is 
important is to examine how 'focus on form' procedures can occur in both approaches and what effect these have on acquisition.

\section{Focus-on-form according to Long}

'Focus on form' was first used by Michael Long but has been borrowed (and extended) by countless scholars and researchers since. A good starting point, however, is to examine how Long's own use of this term has changed over time. To the best of my knowledge, Long first used the term in 1988 in a review of research of instructed interlanguage development. He concluded this article as follows:

.... a focus on form is probably a key feature of second language instruction because of the salience it brings to targeted features in classroom input, and also in input outside the classroom, where this is available. I do not think, on the other hand, that there is any evidence that an instructional program built around a series (or even a sequence) of isolated forms is any more supportable now, either theoretically, empirically, or logically than it was when Krashen and others attacked it several years ago (p. 136: italics in original).

Here Long views FonF and FonFs as 'programs' or 'approaches'. In a later article ("Focus on form: A design feature in language teaching methodology"), Long (1991) elaborated on the differences between these two approaches. FonF 'overtly draws students' attention to linguistic elements as they arise incidentally in lessons whose overriding focus is on meaning or communication' (pp. 45-46). In contrast, FonFs involves traditional language teaching consisting of the presentation and practice of items drawn from a structural syllabus. Later Long (1997) also sought to distinguish 'FonF' from 'focus on meaning' (FonM) - an approach to teaching that emphasized incidental and implicit language learning through content-based instruction or immersion programmes where the learners' focus was more or less entirely on meaning [1].

In a series of articles (Long, 1996; 1997; Long and Robinson 1998), Long drew extensively on research and theory in second language acquisition (SLA) - in particular Schmidt's views about the importance of 'noticing' - to point out the problems with the FonFs and FonM approaches and the strengths of FonF. I have summarized his main points in Table 1. Given that the focus on form needs to occur in a communicative context, it requires the use of 'tasks' that focus learners' primary attention on meaning but also provide periodic attention to form by the teacher and/ or students when this is triggered by communicative need. In other words, focus on form lies at the heart of Long's advocacy of task-based language teaching (TB LT) (see Long and Crookes, 1992). Initially Long conceived of focus on form as providing learners with input (see the quotation from his 1988 article) but by this time focus on form clearly involves production as well as input.

Table 1: Summary of Long's views about three approaches to language teaching

\begin{tabular}{|l|l|l|}
\hline FonFs & FonM & FonF \\
\hline No needs analysis & Usually no needs analysis & A needs analysis of the target \\
\hline
\end{tabular}




\begin{tabular}{|l|l|l|}
\hline & & $\begin{array}{l}\text { tasks learners need to } \\
\text { perform provides the basis of } \\
\text { a task-based syllabus. }\end{array}$ \\
\hline $\begin{array}{l}\text { No realistic models of } \\
\text { language }\end{array}$ & $\begin{array}{l}\text { Older learners cannot fully } \\
\text { acquire an L2 'naturally' and } \\
\text { thus FonM cannot succeed in } \\
\text { enabling such learners to } \\
\text { achieve high levels of L2 } \\
\text { proficiency. }\end{array}$ & $\begin{array}{l}\text { Attracts attention to forms } \\
\text { that otherwise learners might } \\
\text { not notice. }\end{array}$ \\
\hline $\begin{array}{l}\text { Ignores the fact that learning } \\
\text { a new word or rule is a slow } \\
\text { and gradual process }\end{array}$ & $\begin{array}{l}\text { Even prolonged exposure to } \\
\text { the L2 does not ensure that } \\
\text { learners will acquire non- } \\
\text { salient linguistic features. }\end{array}$ & $\begin{array}{l}\text { Allows for the slow and } \\
\text { gradual process involved in } \\
\text { the learning of L2 linguistic } \\
\text { features. }\end{array}$ \\
\hline $\begin{array}{l}\text { Fails to recognize that the } \\
\text { teachability of grammatical } \\
\text { forms is constrained by their } \\
\text { learnability. }\end{array}$ & $\begin{array}{l}\text { Learners need negative } \\
\text { evidence because positive } \\
\text { evidence is insufficient to } \\
\text { guarantee acquisition of } \\
\text { some grammatical features. }\end{array}$ & $\begin{array}{l}\text { Respects the learner's } \\
\text { internal syllabus. }\end{array}$ \\
\hline $\begin{array}{l}\text { Tends to result in boring } \\
\text { lessons. }\end{array}$ & $\begin{array}{l}\text { FonM is inefficient because } \\
\text { it results in only slow } \\
\text { progress }\end{array}$ & $\begin{array}{l}\text { Is under learner control } \\
\text { because it only occurs in } \\
\text { response to the learner's } \\
\text { communication problems. }\end{array}$ \\
\hline $\begin{array}{l}\text { Results in more false } \\
\text { beginners than finishers. }\end{array}$ & $\begin{array}{l}\text { Can result in confidence and } \\
\text { fluency in the use of the L2 } \\
\text { but limited accuracy in use of } \\
\text { the target language system. }\end{array}$ & $\begin{array}{l}\text { Assists the development of } \\
\text { form-function mapping and } \\
\text { so promotes both fluency and } \\
\text { accuracy. }\end{array}$ \\
\hline
\end{tabular}

At this point, then, Long's views about FonF can be characterized as entailing a focus on form that:

- arises in interaction involving the L2 learner

- is reactive (i.e. occurs in response to a communication problem)

- is incidental (i.e. it is not pre-planned)

- is brief (i.e. it does not interfere with the primary focus on meaning)

- is typically implicit (e.g. it does not involve any metalinguistic explanation)

- induces 'noticing' (i.e. conscious attention to target linguistic forms)

- induces form-function mapping.

- constitutes an 'approach' to teaching (i.e. FonF) that contrasts with a traditional formcentred approach (i.e. FonFs).

This characterization of FonF focus on form clearly reflects Long's continuing work on the role of the negotiation of meaning in L2 acquisition and his advocacy of task-based language teaching (TBLT). Initially, Long (1983) emphasized how the negotiation of meaning makes input comprehensible to learners but later, drawing on work by Pica (1992), Long (1996) recognized that negotiation can also provide learners with negative feedback and push them 
to modify their utterances by making them more target-like. For Long, then, the negotiation of meaning was the primary means for achieving a focus on form.

As we will see in the next section, as other researchers and teacher educators have seized on the importance of incorporating attention to form in a communicative curriculum, the scope of the term 'focus on form' has expanded considerably. This is reflected in part in Long's latest definition taken from his 2015 book Second Language Acquisition and Task-based Language Teaching:

Focus on form involves reactive use of a wide variety of pedagogic procedures to draw learners' attention to linguistic problems in context, as they arise during communication in TBLT, typically as students work on problem-solving tasks, thereby increasing the likelihood that attention to code features will be synchronized with the learner's internal syllabus, developmental stage and processing ability ( $\mathrm{p}$. 317).

The essential theoretical foundation remains intact -attention to linguistic form needs to occur in ways that are compatible with how an L2 is acquired by learners. So too is Long's insistence that the focus must be reactive and brief. But it would seem that 'focus on form' is no longer seen as an 'approach' (i.e. FonF) but as a set of procedures. Nor is it just an interactive phenomenon. Also - and in this respect there is major shift - focus on form need not be implicit. Long acknowledges that it can even include provision of an explicit grammar rule as long as this is provided in response to a problem that arises during a communicative exchange. Nor does Long see focus on form as catering just to incidental learning; rather 'intentional learning is brought to the aid of incidental learning, thereby improving the likelihood that a new form-meaning association will be perceived or perceived more quickly' (p. 317). Clearly, focus on form now involves much more than the negotiation of meaning.

This account of the how 'focus on form' has been construed in Long's work is not intended as a critique of Long. The development I have described is quite natural, reflecting Long's response to continuing research and theory development. It does, however, serve as a warning to readers. The term has a long life and lives on but the construct it refers to has changed in quite major ways. In the following section I will attempt my own definition of this construct.

\section{Defining pedagogic focus on form}

'Form' is often misunderstood as referring solely to grammatical form. In fact, 'form' can refer to lexical (both phonological and orthographic), grammatical, and pragmalinguisticfeatures. However, in this review I will mainly address grammar. Also the term 'focus on form' is somewhat misleading as the desired focus is not just on form but on form-meaning mapping (e.g. the use of the -ed morpheme to denote past time or the pronunciation of a word like 'alibi' so that its meaning can be understand by listeners) as Long made clear.

We have seen that Long defined FonFs as involving the explicit teaching of linguistic forms based on a structural syllabus. The problem here is that explicit language teaching can also 
include activities designed to focus learners' attention on form in communicative activities. For example, the final stage of presentation-practice-produce (PPP) involves such activities. To address this difficulty, Doughty and Williams (1998a) emphasized that FonF and FonFs 'are not polar opposites' and that the essential difference is that FonF entails a focus on formal elements of language, whereas FonFs is limited to such a focus' (p. 4; italics as in original). Thus, whereas PPP might initially be viewed as a FonFs approach as it is based on a structural syllabus and involves the explicit presentation and controlled practice of discrete linguistic features, it can be seen as including a focus on form as it is not limited to a focus on purely formal elements. Indeed, the collection of articles on focus on form that Doughty and Williams (1998b) edited includes one by DeKeyser (1998) that draws on skill learning theory to promote PPP. Thus PPP is now seen as incorporating focus of form.

This, however, is quite clearly incompatible with both Long's early and later accounts of focus on form. There is a fundamental difference between a synthetic approach involving the linear teaching of discrete linguistic features and an analytical approach where attention to form only emerges out of the efforts to comprehend and produce meaningful texts in the L2. The problem here lies in trying to characterize FonF and FonFs as approaches. As I have argued elsewhere (Ellis 2015), focus on form is best understood not as an approach (i.e. as FonF) but as involving different kinds of instructional procedures. That is, focus on form entails various techniques designed to attract learners' attention to form while they are using the L2 as a tool for communicating. In contrast, focus on forms entails various devices (such as 'exercises') designed to direct learners' attention to specific forms that are to be studied and learned as objects.

Treating focus on form as procedures also avoids another problem, namely whether it can only take place incidentally (as Long initially envisaged) or can be pre-planned. Clearly, in PPP the focus on form in the production activity must be planned. This can be achieved by designing focused tasks (Ellis 2003) intended to elicit the use of a pre-planned target feature(s) in a context that is communicative. The activities in which focus on form occurs, then, can be either unfocused (i.e. designed to simply elicit general samples of the L2) leading to incidental attention to a variety of forms) or they can be focused leading to a predetermined and intensive focus on a specific form(s). In the case of the latter a focus-on-form activity can be incorporated into a synthetic approach such as PPP, which some commentators (e.g. Fotos, 1998; Littlewood, 2007) have argued is needed in contexts where the L2 is a foreign rather than a second language and where there is an expectancy that the language will be taught explicitly.

I noted that Long initially viewed focus on form as an interactional phenomenon. That is, it occurred when a communication problem arose and was addressed while learners were interacting with the teacher or other learners and negotiation of meaning occurred. Other researchers (e.g. Lyster 2001; Ellis, Basturkmen \& Loewen 2001), however, have noted that the same kinds of interactional sequences can occur in a classroom where there is negotiation of form (i.e. negotiation occurs even though there is no communication problem). 
Long also insists that focus on form occurs as a response to a problem. This also seems far too narrow. As Ellis, Basturkmen \& Loewen (2001) noted in their study of focus on form episodes in communicative ESL classes, there are occasions when teachers pre-empt a problem, for example, by reminding students they need to pay attention to a particular grammatical feature when they perform a task and learners also sometimes pre-empt as when they initiate questions about linguistic forms. These focus on form episodes are designed to avoid rather than repair a linguistic problem but they are clearly still problem-oriented. Interactive focus on form, then, can be defined as the pre-emptive or responsive attention to form that occurs during an activity that is primarily meaning-focused and that addresses either a communicative or linguistic problem.

Interactive focus on form certainly allows for relatively implicit ways of focusing on form, which was initially seen as a defining feature of focus on form. However, as Long (2015) later came to recognize, focus on form can at times be quite explicit and even involve metalinguistic comments. When learners are engaged in a communicative activity they often participate in 'language related episodes' (LREs), defined by Swain (1998) as 'any part of a dialogue in which students talk about the language they are producing, question their language use, or other- or self-correct' (p. 70). LREs are clearly instances of focus on form and typically involve explicit attention to form.

However, as Long (2015) came to recognize, focus on form can also be non-interactive as when learners are asked to process oral or written input where specific target features have been highlighted (i.e. enhanced input). In this case the primary focus is on comprehending the input but learners' attention is also attracted to the target feature(s). Non-interactive focus on form has also attracted considerable research.

Focus on form - both interactive and non-interactive - can vary in how obtrusive it is (i.e. how much it interferes with communication). Doughty and Williams (1998c), for example, offer a taxonomy of focus-on-form techniques that vary in terms of the extent to which they interrupt the flow of communication. For example, 'input flood' is viewed as minimally obtrusive, corrective recasts as more obtrusive while 'input processing' involving structured input (VanPatten, 1996) is very clearly obtrusive. The more obtrusive techniques, however, might be better classified as focus-on-forms techniques as arguably they direct rather than attract attention to form. Perhaps, though, focus on form and focus on forms activities should be seen as placed on a continuum depending on the extent to which they cater to explicit or implicit attention to form.

Central to all these senses of focus on form is that learners' attention is attracted to formmeaning mapping while they are engaged in an activity where the primary focus is on meaning. Skehan (1996), however, proposed that a focus on form can be induced outside of the performance of a communicative activity by providing time for pre-task planning. As Ortega (1999) put it, 'the provision of time for learners to plan is a pedagogical manipulation assumed to induce learners to focus on whatever formal and systemic aspects of the language are needed to accomplish a particular task (p. 110). This manipulation may also lead to 
enhanced attention to form when learners perform the task. Asking learners to repeat a task can also lead to enhanced focus on form (Bygate, 1996).

Figure 1 schematizes the various ways in which a focus on form, as pedagogical activity, can take place. Clearly an expanded definition of focus on form is needed. Drawing on the definition proposed by Nassaji \& Fotos (2010), I propose the following:

Focus on form occurs in activities where meaning is primary but attempts are made to attract attention to form. Thus it is not an approach but rather a set of techniques deployed in a communicative context by the teacher and/ or the learners to draw attention implicitly or explicitly and often briefly to linguistic forms that are problematic for the learners. The focus on form may be pre-planned and thus address a pre-determined linguistic feature(s) or it can be incidental as a response to whatever communicative or linguistic problems arise while learners are primarily focused on meaning. Focus on form activities can be interactive or non-interactive and involve both production and reception. They can be found in both explicit and implicit approaches to language teaching. They can also occur before a communicative task is performed or while it is being performed [2].

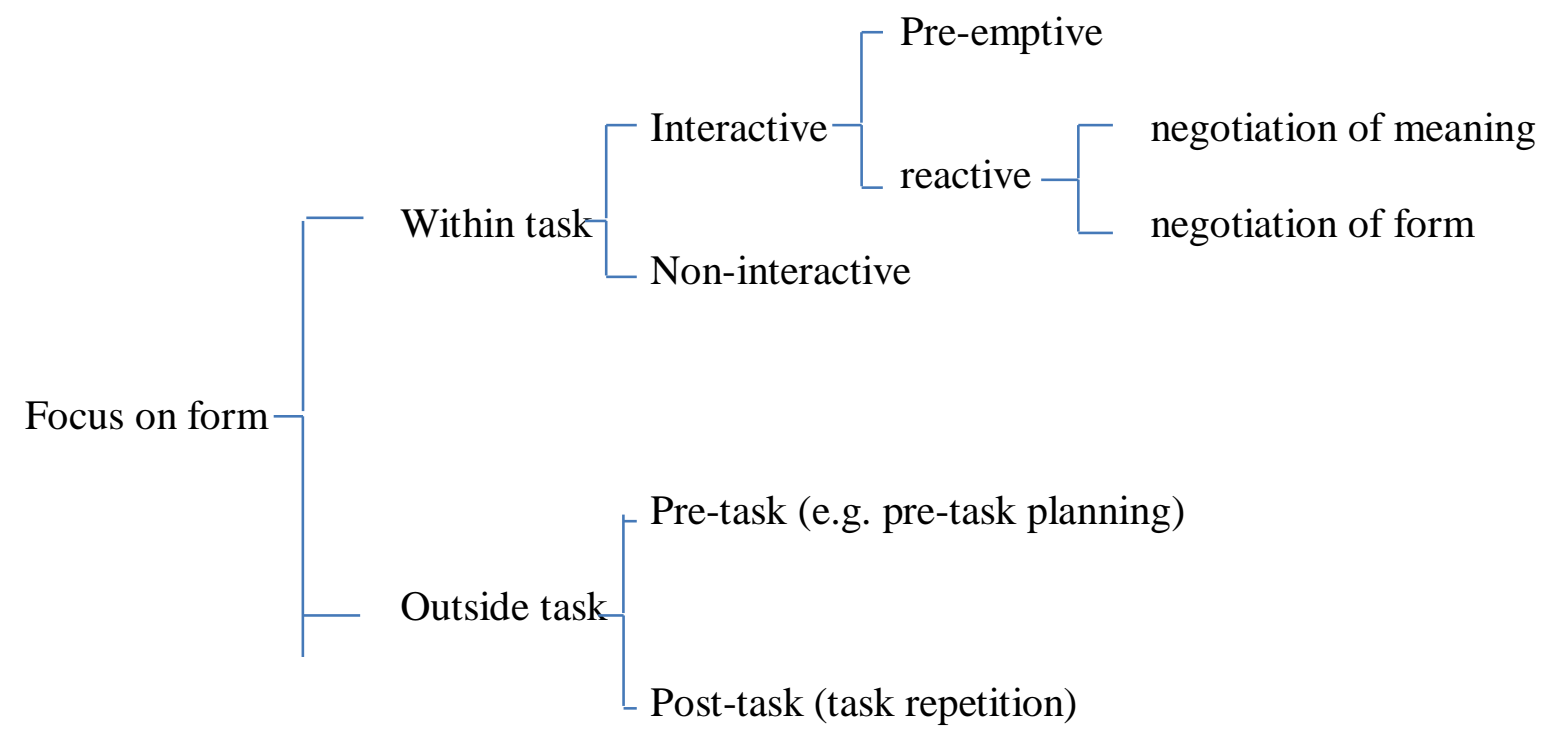

Figure 1: Types of focus on form activities

\section{The psycholinguistic dimension of focus on form}

Focus on form can also be viewed from a psycholinguistic perspective by considering 'the cognitive correlates of the components of focus on form' (Doughty, 2001:211) as these relate to both language use and learning. Two key cognitive constructs (selective attention and cognitive comparison) along with the memory systems (working memory and long-term memory) that support the functioning of these constructs underlie psycholinguistic accounts of focus on form.

\section{Selective attention}


Selective attention refers to the act of purposively focusing conscious attention on some particular object or goal while ignoring extraneous information that may be present in the situational context. In the case of language, attention may be selectively focused on meaning or on form. In focus on forms activities attention is intended to be selectively focused on linguistic form. In focus on form activities attention is selectively focused on meaning but may also from time to time be voluntarily or involuntarily focused on specific linguistic forms that occur in the input or that the learner needs to express a particular meaning. This is can occur when learners become aware of a 'hole' in their existing L2 knowledge (Swain, 1998), which prevents them from expressing what they want to say. As a result they are sensitized to attend to input containing the linguistic forms they need or to request assistance from the teacher or another learner (a pre-emptive type of focus on form).

A key issue - one that continues to be debated in SLA circles - is whether the attention to form that occurs while learners are primarily focused on meaning necessarily involves conscious awareness. Schmidt $(1994 ; 2001)$ considered that in general learning is only possible if attention to form is conscious, i.e. 'noticing' occurs. In contrast, Tomlin and Villa (1993) argued that what they called 'detection' can occur without conscious awareness. N. Ellis (2005) suggested that conscious attention is needed in order to establish a new form in long-term memory but that subsequently attention to this form in the input can occur subconsciously, strengthening and modifying the initial neural connections. Irrespective of whether focus on form involves conscious noticing or subconscious attention it caters to incidental learning, that is, learning that takes place without intention while selective attention switches briefly from meaning to form.

There is now sufficient evidence to show that purely implicit learning is possible (see $\mathrm{J}$. Williams, 2009). However, there is also evidence to suggest that when the focus on form leads to learners consciously attending to linguistic forms they are more likely to learn what they have attended to (Mackey, 2006). Whether noticing of form is needed is likely to depend on the salience of the linguistic feature. Features that are salient and communicatively functional in context (e.g. lexical items or grammatical features such as plural-s) may be acquired implicitly whereas features that are non-salient and communicatively redundant (e.g. 3rd person-s) may only be acquired if they are explicitly noticed. This raises the likelihood that different kinds of focus on form may be needed to facilitate the acquisition of different linguistic features. For example, recasts (generally considered an implicit type of focus on form) may facilitate the acquisition of salient/non-redundant features but explicit correction may be needed for non-salient/ communicatively redundant features.

\section{Cognitive comparison}

The learning of new forms can take place when learners simply attend to linguistic forms in the input but it can also take place when they express their meaning using an erroneous linguistic form and receive corrective feedback (a reactive type of focus on form). In these ways focus on form can help learners to compare the current state of their L2 knowledge with the input they are provided with. As Doughty (2001) pointed out, this involves establishing a link between input held in a temporary perceptual store and already-stored L2 knowledge. 
The importance of making cognitive comparisons for L2 acquisition was first recognized in Schmidt and Frota's (1986) study of the first author's acquisition of L2 Portuguese. Schmidt became aware that he frequently engaged in 'noticing-the-gap' between his own output and the input he was exposed to as in this example: 'I often say dois anos ante for 'two years ago. I think it should be anos atras. I have been hearing it that way in conversation ...'. The cognitive comparison in this example is clearly a very conscious process but in interactive focus-on-form episodes may lead to 'detection' without any conscious awareness. In the example below, the teacher recasts the learner's utterance:

Learner: No go disco this Saturday.

Teacher: Oh so you're not going to the disco this Saturday.

This affords the learner an overt comparison between his erroneous utterance and the target form and an opportunity for the learner to carry out the kind of the mental comparison hypothesized to assist the restructuring of the L2 system However, for such restructuring to take place, the learner will need to engage in some analysis of the recast. That is, the learner needs to compare not just 'no go' with 'you're not going' but rather the underlying negative patterns (i.e. 'no + verb' and 'auxiliary + not + verb'). Only then can the learner recognize that the target version of his utterance is 'I'm not going'. In other words carrying out a cognitive comparison may often involve more than just attending to the surface differences between the learner's own utterance and the target language input.

Doughty and Williams (1998a) proposed that there is a 'cognitive window' for carrying out cognitive comparisons and suggested that this can last up to 40 seconds if learners are able to rehearse what they have just heard in their perceptual memory. However, Doughty \& Williams clearly had interactive focus on form in mind. Non-interactive focus on form involving enhanced input potentially allows the learner much longer to carry out the comparison as it does not occur in online processing.

The timing of focus on form

A key issue is the timing of focus-on-form. Doughty (2001) discussed four possibilities:

1. Simultaneous processing (i.e. attention to form and meaning occur conjointly).

2. Focus on form in advance (i.e. priming the learner to attend to specific forms, for example by pre-teaching the forms, prior to their engagement in a communicative task).

3. Shifts of attention during processing (i.e. selective attention is temporarily switched to form).

4. Immediately contingent focus on form (i.e. attracting learner' attention to a specific form in the previous utterance, for example by means of a recast).

There are doubts about L2 learners' ability to engage in simultaneous processing of meaning and form. Especially when learners' proficiency is weak, the difficulty experienced in decoding and encoding for meaning may inhibit attention to form (see VanPatten, 1990). Pre- 
teaching the target form may help learners to attend to it while communicating and may also facilitate learning (see, for example, studies by Lyster (2004) and Cintron-Valentin and Ellis (2015)). Pre-task planning can also be seen as a pre-emptive focus-on-form strategy that helps learners attend to form while performing a communicative task. Temporary shifts in attention can occur as a result of both pre-emptive and reactive focus on form. Studies by J. Williams (2001) and Loewen (2005) provide evidence that this happens with some frequency in task-based interactions and can lead to learning. Immediately contingent focus on form through recasting is favoured by both Long (1996; 2006) and Doughty (2001) on the grounds it brings together input, learners' internal cognitive processes (such as noticing and noticingthe-gap) and output and thus facilitates cognitive comparison without interrupting the flow of communication. In this way, so it is claimed, recasts create the ideal conditions for implicit learning. There is now substantial evidence that recasts do facilitate attention and learning (see, for example, Goo \& Mackey, 2013) but as several commentators have pointed out (Nicholas et al 2002; Ellis \& Sheen, 2006) recasts vary in terms of how implicit and explicit they are and learners are more likely to benefit if the recasts are intensive and explicit as in Doughty and Varela's (1998) study of corrective recasts (i.e. recasts preceded by a repetition of the learner's erroneous utterance with the incorrect elements highlighted). There are also other ways of achieving an immediately contingent focus on form by prompting learners to self-correct with some researchers (e.g., Lyster (2004) and Kartchava and Ammar (2014)) arguing that prompts such as requests for clarification and elicitations are more likely to bring about changes in the learners' L2 system than recasts because they induce learners to produce the target forms whereas recasts frequently to not lead to self-correction

From a psycholinguistic and pedagogic standpoint it is important to investigate these different ways of timing a focus on form In the classroom, opportunities will exist for the simultaneous processing of form and meaning, focusing on form in advance of a communicative activity (for example, by means of direct instruction), temporary shifts of attention from meaning to form, and immediately contingent focus on form. If what is important is that learners' attention to form takes place while they are primarily engaged in meaning-making (either receptively or productively), then, all four ways of timing have merit. To date, however, we have no understanding of whether some of these ways are more effective for learning than others.

\section{Working memory and focus on form}

In order to explain how focus on form can contribute to acquisition researchers are increasingly drawing on models of working memory on the grounds that the processing of focus-on-form interventions must necessarily involve (1) temporary storage of input and output and (2) establishing links with long-term memory. While there are a number of different models of working memory (see Wen, 2015), they all acknowledge that working memory is limited in capacity and functions as a site where information can be (1) temporarily stored, (2) rehearsed to prolong activation (3) and processed by establishing links with long-term procedural and declarative memories. In terms familiar to SLA researchers, the functioning of working memory enables 'intake' to be incorporated into the learner's 
interlanguage system either as implicit knowledge in procedural memory or as explicit knowledge in declarative memory.

We noted earlier that learners may have difficulty in attending simultaneously to both meaning and form. This can be explained by the limited capacity of working memory. Skehan's (1998; 2009) Trade-Off Hypothesis proposes that learners will prioritize one aspect of language use over others - for example, meaning over form or, in the case of form, complexity over accuracy. Skehan is less concerned with how instructional interventions can attract learners' attention to specific linguistic forms (as in mainstream accounts of focus on form) than with how the particular focus-on-form strategy he is most interested in (pre-task planning) can orientate learners generally to form as opposed to meaning and to complexity as opposed to accuracy. Drawing on Levelt's (1989) model of speaking, he suggests that pretask planning aids conceptualization (i.e. deciding what to say) thus enabling learners to pay greater attention to formulation (i.e. accessing the lexical and grammatical features needed to encode what is to be said) during actual production when performing a task. Also, as Ortega (1999) showed, planning may enable learners to activate their existing linguistic resources in working memory thus enabling ready access to these again when they perform the task.

Models of working memory also provide a basis for addressing whether focus on form results in changes in procedural memory (i.e. implicit knowledge) or declarative memory (i.e. explicit knowledge). This is another key issue for focus-on-form researchers. One reason why Doughty (2001) favoured immediate contingent focus on form was because she considered it assists the development of true linguistic competence (i.e. implicit knowledge). This is most likely to occur if the focus on form leads to temporary storage of the targeted features in learners' phonological short-term memory. In contrast, if there is time for analysis of the input, deeper processing involving declarative memory may take place resulting in explicit knowledge. Révész's (2012) study lends support to such a possibility. She investigated the relationship between gains in grammatical accuracy following recasting. She reported that differences in the learners' phonological working memories were related to accuracy gains in an oral description task whereas differences in their complex working memory were related to gains in a written test. She then interpreted these results as showing that how the learners processed the recasts in working memory affected whether development led to procedural or declarative knowledge

It is becoming clear that the role of working memory in processing focus-on-form interventions is complex. Simplistic notions that learners with larger working memories will benefit more from focus on form are giving way to more nuanced positions that distinguish how different aspects of working memory are involved in processing different types of focus-on-form interventions.

\section{The discoursal dimension of focus on form}

In a task-based approach focus on form can be achieved interactively by means of the negotiation of meaning or form and non-interactively (see Figure 1). It is the interactive focuson-form, however, that attracted the greatest attention of SLA researchers such as Long, 
Doughty, Mackey and R. Ellis on the grounds that it is interaction that plays the central role in both first language acquisition and naturalistic L2 acquisition.

Ellis, Basturkmen and Loewen (2002) identified a set of 'options' for 'doing focus-on-form'. They distinguished two basic types of focus on form: reactive and pre-emptive focus on form, Each of these two types of can be realized by means of a number of discoursal strategies. Reactive focus-on-form can be conversational or didactic. Conversational focus-on-form occurs when the attention to form arises in the course of dealing with a communication problem resulting in the negotiation of meaning. Didactic focus-on-form occurs when attention to form arises even though no communication problem has occurred. In this case, negotiation of form rather than negotiation of meaning takes place. Pre-emptive focus-onform can also take a number of forms. It can be student-initiated as when a student asks a question about a linguistic form or it can be teacher-initiated. In this latter case the teacher may pre-empt by means of a query to check whether students know a particular linguistic form or the teacher may directly advise students to take care that they use a particular linguistic feature correctly as, for example, by reminding them to use the past tense in an activity involving the reporting of an accident.

There is now a substantial body of descriptive classroom-based research that has investigated the discoursal aspects of focus-on-form. A full review of the descriptive studies of focus on form is not possible in the space of this article so instead I will summarize the main findings and cite studies that are illustrative of these.

1. In lessons where there is a primary focus on meaning, focus on form occurs frequently (Ellis, Basturkmen \& Loewen, 2001); Nassaji (2010). Often, however, teachers are not aware of the extent to which they engage in focus in form (Basturkmen, Loewen \& Ellis, 2004).

2. Both teachers and learners vary in the extent to which they engage in focus on form (Loewen, 2003).

3. Both learners and teachers sometimes make effective use of the learner's L1 to address linguistic problems in the L2 when performing communicative tasks (Nakatsukasa \& Loewen, 2015; Storch and Wigglesworth, 2003).

4. By and large, focus on form episodes are triggered by lexical or grammatical problems. In a classroom context, relatively few episodes concern pragmatic aspects of language (Ellis, Basturkmen \& Loewen, 2001).

5. The instructional context affects the frequency with which different focus on form options occur and also the extent to which they result in uptake with repair (Sheen, 2004) [3]. In part this depends on the extent to which the learners' general orientation is to meaning or form.

6. The extent to which learners notice those forms that are focussed on during communicative interactions varies according to a number of factors such as whether the form receiving the focus is relevant to the learners' communicative needs ( $\mathrm{J}$. Williams, 2001) and the discoursal characteristics of specific focus on form options, in particular their level of explicitness (Egi, 2007).

7. While uptake-with-repair cannot be taken as evidence of learning, in some studies it has been found to be facilitative of learning (Loewen and Philp, 2006). Nassaji (2011) 
showed that the relationship between uptake/repair with learning depended on the type of repair with a stronger relationship between the two when the repair involved incorporation of the target form into new utterance than when it involved repetition of the feedback.

8. Both focus on form initiated by learners in learner-learner interaction and by teachers in whole-class interaction benefit acquisition (J. Williams, 2001; Loewen, 2005).

9. In interactions involving the teacher there is evidence that pre-emptive focus on form is more effective than reactive focus on form especially if it is the learner who preempts (Nassaji, 2013).

10. The effectiveness of focus on form also differs according to the participation structure, with a stronger effect evident when the teacher participates in small group work than in whole-class interaction (Nassaji, 2013).

11. The extent to which learners participate in and benefit from focus on form depends on their L2 proficiency with higher proficiency learners focusing on form more and benefitting more from it than lower proficiency learners (J. Williams, 2001). Nassaji (2010) found that the effectiveness of reactive and pre-emptive focus on form also differed depending on learners' language proficiency and class level, with advanced level learners benefiting more from reactive focus on form than less advanced learners.

\section{The effects of different types of focus on form}

In this section I will review research which has investigated the different types of focus on form shown in Figure 1.

\section{Text-enhancement}

The research on text-enhancement suggests that text-enhancement is effective in helping learners to notice the target feature but not always so (Lee \& Huang, 2008). There are a number of factors that influence whether noticing occurs. In part it depends on the nature of the target structure. Some structures are more salient than others. Learners may also be more likely to attend to a grammatical form if they have already partially acquired it and/ or have explicit knowledge of it than if it is a completely new form. The main constraint, however, is the learner's level of proficiency. Less proficient learners may struggle to engage in dual processing - comprehending the meaning of the text and consciously attending to linguistic form - and are likely to prioritize meaning over form. Studies (e.g. Shook, 1999) have shown that if learners engage in the top-down processing required for comprehension, less noticing of specific forms occurs.

Even if learners do notice the target feature, they may not acquire it. Noticing affects intake but not everything that is taken into working memory passes into long term memory. Lee \& Huang's (2008) meta-analysis examined 20 text-enhancement studies. They reported an overall positive effect in tests administered shortly after the learners had completed reading the enhanced texts but acknowledged that this was quite small and also that there were marked 
differences in the results of individual studies. Lee \& Huang also reported that the benefits of the exposure tended to wear off over time.

Overall, text-enhancement does not emerge as a very effective type of focus on form unless it is combined with other instructional techniques that encourage intentional learning. When performing a task that prioritizes comprehension, learners may rely on top-down processing and pay little attention to the enhanced elements.

\section{Corrective feedback}

Corrective feedback $(\mathrm{CF})$ constitutes a reactive type of focus on form that occurs in both the negotiation of meaning and of form [4]. It involves a number of different strategies that can be classified in terms of whether they are (1) implicit/ explicit and (2) input-providing/ output-prompting strategies (see Table 4).

Table 4: Types of corrective feedback (adapted from Lyster, Saito \& Sato, 2013: 3)

\begin{tabular}{|l|l|l|}
\hline & Implicit & Explicit \\
\hline Input-providing & Conversational recasts & $\begin{array}{l}\text { Didactic recasts } \\
\text { Explicit correction } \\
\text { Explicit correction + } \\
\text { metalinguistic explanation }\end{array}$ \\
\hline Output-prompting & $\begin{array}{l}\text { Retalinguistic comments } \\
\text { Elicitation } \\
\text { Paralinguistic signal }\end{array}$ \\
\hline
\end{tabular}

No type of focus-on-form has received more attention than corrective feedback. In addition to a number of descriptive studies (e.g. Chaudron, 1977; Lyster and Ranta, 1997; Sheen, 2004), there are now numerous experimental studies. A number of meta-analyses of CF studies are now available (Russell \& Spada, 2006; Mackey \& Goo, 2007; Li, 2010; Lyster \& Saito, 2010) [5]. All these meta-analyses reported that CF has a sizable positive effect on L2 learning. In general, explicit types of feedback are more effective than implicit. Ellis, Loewen \& Erlam (2006), for example, reported that repetition followed by metalinguistic feedback led to greater gains in tests designed to measure both implicit and explicit knowledge of the target structure (past tense $-e d$ ) than recasts. However, Li's (2010) meta-analysis found that implicit CF proved to be more effective in post-tests completed a long time after the instruction. Perhaps, then, the effects of implicit CF, like a good wine, need time to mature.

Lyster and Saito's (2010) meta-analysis, which focussed exclusively on classroom studies of corrective feedback, compared the relative effects of input-providing CF (recasts) and outputprompting CF. They reported that both recasts and prompts are effective in promoting acquisition but the effect size for prompts $(0.83)$ was appreciably larger than that for recasts (0.53). However, the relative effectiveness of recasts and prompts has continued to be debated - see, for example, Goo \& Mackey (2013) and Lyster \& Ranta (2013). Perhaps it is fundamentally mistaken to look for the most effective type of corrective strategy. Different strategies may prove effective for learners at different developmental levels as claimed by 
sociocultural theorists such as Aljaafreh \& Lantolf (1994). Also individual differences in language aptitude or working memory may affect learners' ability to process the different strategies as suggested by Révész's (2012) study, which I considered earlier.

Researchers have also investigated whether the corrections that learners receive are noticed and whether 'noticing' promotes learning. There is clear evidence that learners do notice the corrections their receive even in implicit types of CF such as recasts (Egi, 2007) but to date there is little evidence to show a consistent direct effect of such noticing on acquisition (see, for example, Mackey (2006).

A few studies have also investigated whether learner-generated CF results in learning. Adams (2007) recorded interactions while learners were performing tasks in pairs, identified corrective feedback sequences, and then administered tailor made tests to assess whether learning had taken place. She reported that over $60 \%$ of the feedback episodes led to learning. McDonough (2004) investigated learner-learner corrections directed at conditionals when performing a focussed task designed to elicit the use of this structure. She reported that those learners who participated more frequently in the corrective feedback were the ones who showed significant improvement in oral tests that elicited use of conditionals.

The results of the CF research provide the clearest support for focus on form. Correcting learners' errors while they are communicating is a highly effective way of drawing their attention to form and there is clear evidence that $\mathrm{CF}$ facilitates acquisition. On balance $\mathrm{CF}$ is more effective if it is explicit, presumably because it is more likely to guarantee a switch in selective attention to form. But implicit forms of CF such as recasts have also been found to be effective and may even have a greater long-term effect. CF is likely to be more intensive when it is in the hands of the teacher but it also occurs in learner-learner interactions and contributes to learning.

\section{Pre-task planning}

As noted earlier, pre-task planning serves to alleviate the problems that learners face in L2 production due to the limited capacity of their working memories. It facilitates 'planned language use', which, as Ochs (1979) noted, is characterized by more complex, target-like forms than unplanned language use.

The bulk of the research has investigated what effect pre-task planning has on the complexity, accuracy and fluency of learners' language when they perform the task. This research is reviewed in R. Ellis (2009). Pre-task planning studies distinguish 'guided planning' where learners are directed to pay attention to some specific aspect of language (i.e., form or meaning) or even some specific grammatical feature and 'unguided planning' where they left to decide for themselves what aspects they plan. In a survey of planning studies, Ellis (2009) found that both had a positive overall effect on fluency except if the task was performed in a testing (as opposed to teaching) context. Interestingly, however, in one study of guided planning where learners were asked to focus their planning on a single grammatical structure (Mochizuki \& Ortega, 2008), fluency did not benefit. Pre-task planning also benefited complexity (especially grammatical complexity) in 13 of the 19 studies Ellis 
included in his review. A similar number of studies also reported it had an effect on accuracy. Some studies reported that pre-task planning aided complexity but not accuracy and viceversa lending support to Skehan's (2009) Trade-off Hypothesis. However, these generalizations are quite crude and, as Ellis' review showed, factors such as the nature of the task, the length of the planning time and the learners' level of L2 proficiency mediated the effects of the pre-task planning in complex ways.

The effect that pre-task planning has on task performance will obviously also depend on what learners do while they plan. Some studies have investigated this (e.g. Ortega 1999, 2005; Mochizuki \& Ortega, 2008; Pang \& Skehan, 2015). The guided planning in Mochizuki \& Ortega led to more accurate uses of the target structure (relative clauses) than did unguided planning but, importantly, it also resulted in similar levels of global complexity and fluency. Pang \& Skehan attempted to relate coded features of the learners' unguided planning to measures of complexity, accuracy and fluency derived from their performance of the task. They reported that a general focus on grammar had a negative impact on complexity and fluency without enhancing accuracy and concluded 'focusing on grammar confers only disadvantages and no advantages' (p. 120). Clearly, more work is needed on how specific planning strategies and foci affect performance of a task but if these two studies are indicative, it is the guided planning that focuses on a specific linguistic feature that is needed to achieve an effect on accuracy.

\section{Task-repetition}

When learners are asked to repeat the same task, the first performance functions in much the same way as pre-task planning - it enables learners to both conceptualize what to say and select the language needed to say it. Potentially, then, it enables learners to focus attention more closely on linguistic form in the repeat performance. It can be expected then that task repetition will have a similar effect on complexity, accuracy and fluency as pre-task planning.

However, the results of task-repetition studies have produced somewhat mixed results along with evidence of trade-off effects in the repeated task. Bygate $(1996 ; 2001)$, for example reported that fluency and complexity increased in the repeated task but not accuracy. Lynch $\&$ McLean (2000) found that repetition led to increased accuracy in low proficiency learners but to more complex language in higher proficiency learners. Gass et al (1999) found an effect for repetition on the accurate use of a specific grammatical feature. However, none of these studies found evidence of any transfer-effects to a new task. Bygate (2001) suggested that 'massed' repetition practice may be needed for such transfer effects to occur. Perhaps, though, what is needed is some kind of intervention between performances of the same task to induce attention to form. Sheppard (2006) tried providing learners with input and feedback between performances and found that both led to improvements in complexity, accuracy and fluency in the repeat performance and also in complexity (but not in accuracy or fluency) in the performance of a new task.

\section{Critiques of focus on form}


Focus on form is a crucial feature of task-based language teaching. Not surprisingly, then, it has attracted considerable criticism from advocates of more traditional approaches to teaching such as FonFs. The main objections to TBLT and FonF (as an approach) are as follows:

- FonF is based entirely on theoretical hypotheses (e.g. Schmidt's Noticing Hypothesis) that are themselves lacking in empirical support (Swan, 2005).

- Focus on form consists only of quick feedback on learners' errors while they are performing a communicative task (Sheen, 2003).

- Advocates of FonF present it as the only theoretically-sound way of teaching an L2, rejecting FonFs entirely (Swan, 2005).

- There is no report of any successful long-term implementation of FonF (Sheen, 2005)

- There is no evidence to show that FonF results in superior L2 learning than FonFs (Sheen, 1994).

- FonF is an experiential approach to language teaching that is ill-suited to cultures of teaching and learning that are different from those of Western settings (Littlewood, 2007; 2015).

Most of these objections are entirely misplaced reflecting fundamental misunderstandings about task-based language teaching and the role of focus on form (see Ellis, 2009). There is ample evidence to support theoretical hypotheses such as the Noticing Hypothesis and also to show that focus on form results in learning (see previous sections). Focus on form involves much more than quick feedback on learner errors - as defined in this article it includes, for example, text-enhancement, pre-task planning and task- repetition. Not all advocates of TBLT reject FonFs; R. Ellis (2003; 2009), for example, suggests that a modular system that includes both a FonFs and a TBLT component might be best suited to some instructional contexts. Also, if focus on form is viewed as a set of procedures rather than as an approach as I have argued it should be - then clearly it has a place in any approach that includes communicative tasks, including PPP. There is also evidence that a task-based approach that incorporates focus on form can be successfully implemented and is effective (e.g. Prabhu, 1987; chapters in Van den Branden, 2006). The cultural inappropriateness of a focus on form approach, however, is a more weighty criticism, which I will return to in the conclusion section of this paper.

\section{Comparative studies of FonF and FonFs}

There are no global comparative method studies that have investigated the relative effectiveness of FonF and FonFs in developing general L2 proficiency, reflecting the difficulty of achieving internal and external validity in the design of such studies (see R. Ellis, 2012). However, there are a number of 'local' comparative studies, which have investigated these two approaches in terms of their effect on the acquisition of specific target language features. Sheen $(2003 ; 2005)$ has argued that such studies are needed

Several studies examined their relative effectiveness of FonF and FonFs on the acquisition of vocabulary but, for reasons of space, I will only consider those studies that investigated 
grammar. Sheen (2006) found that FonFs instruction led to greater learning than FonF but this study was seriously flawed. Sheen admitted that the FonF instruction in his study was not properly implemented as the teacher failed to correct the learners' errors consistently while they were performing the communicative tasks (i.e. in other words there was very little focus on form). Also the tests in his study all involved controlled production of the target features and so favoured the FonFs group Shintani (2015) investigated the incidental acquisition of grammar in FonF and FonFs instruction. The instructional materials in both approaches exposed the learners to exemplars of grammatical structures while the instructional target was vocabulary. Shintani reported that FonF led to greater incidental learning, which was attributed to the fact that it created a greater functional need to attend to the target structures and afforded more opportunities for noticing them. However, this was only true for one of the structures - the meaning-bearing grammatical morpheme (plural-s) - and not for the nonmeaning bearing structure (copula be). This is a still noteworthy finding, however, as any kind of instruction affords opportunities for incidental learning and it is helpful to know what kind of instruction promotes it most effectively.

These studies only go some way to addressing Sheen's (2006) call for comparative studies of FonF and FonFs and they certainly do not allow any clear conclusions to be reached. They demonstrate the problems of designing such comparative studies and also the importance of examining the classroom processes associated with the two types of instruction in order to understand how these shape opportunities for learning and can help to explain the test results. However, as I will argue below, it is perhaps time to abandon even such 'local' comparative method studies and focus instead on how specific options of both the focus-on-form and focus-on-forms kinds direct or attract learners' attention to form and what their impact on learning is.

\section{Conclusion}

This review of focus on form has raised a number of points:

1. 'Focus-on-form' refers not just to form but to form-function mapping.

2. Focus on form was first introduced as a pedagogic approach (FonF) that was seen as an alternative to a structured-based approach (i.e. FonFs). Subsequently, however, focus on form came to be viewed as a set of procedures for attracting attention to form that can figure in both approaches.

3. The scope of pedagogic focus on form has expanded considerably over the years, however. Initially, it referred to the interventions designed to attract learners' attention to form while they performed a communicative task. Later it was expanded to include interactive and non-interactive ways of drawing attention to form both prior to and after performance of a task.

4. Central to all kinds of focus on form instruction, however, is some kind of meaningfocused task that provides the context for the focus on form. Thus focus on form is integral to task-based language teaching.

5. There is well-defined psycholinguistic dimension to focus on form. To understand this it is necessary to consider, in particular, the role of selective attention and cognitive 
comparison in language learning as these occur when learners process language in their working memories. The limited capacity of WM constrains what learners can attend to while communicating and thus influences what they can focus on and learn.

6. There is also an important discoursal dimension to interactive focus-on-form. Descriptive research has identified a number or pre-emptive and reactive strategies that can be used to address form and how these strategies impact on learner production (for example, uptake with repair) and learning.

7. Experimental studies of focus-on-form have shown that it facilitates L2 acquisition although this depends on a number of factors such as the salience of the focus on form and the learners' L2 proficiency. Reactive focus-on-form (i.e. corrective feedback) has been shown to be especially facilitative although focus on form undertaken preemptively also aids learning as does non-interactive enhanced input.

8. Pre-task planning and task-repetition have been shown to influence how learners orientate to the performance of a communicative task and impact on the complexity of the language involved.

9. FonF as a pedagogic approach has been the subject of considerable criticism. Many of the objections are spurious resting on the misconception that it constitutes a uniform approach consisting solely of task-induced interaction and on the failure to acknowledge the substantial empirical evidence that lends support to it.

10. Calls for comparative studies of FonF and FonFs have been answered but the research to date does not allow a clear answer as to their relative effectiveness. There is evidence, however, that FonF results in richer types of classroom interaction that benefit the incidental acquisition of non-targeted features.

I have dismissed many of the criticisms of FonF as an approach but I acknowledge that there can be problems in implementing it. A number of teacher educators (e.g. Bax, 2003) have argued it is necessary to take account of the particular instructional context before deciding which approach to use. Thus, for example, in a context such as China, where 'education is conceived more as a process of knowledge accumulation than as a process of using knowledge for immediate purposes' (Littlewood; 2015: 653), a communicative or task-based approach may be seen as culturally inappropriate. In such contexts the teachers' unfamiliarity with focus on form, the learners' concern with language as an object rather than as a tool for communicating, and an educational system that requires students to take traditional type tests to progress academically all constitute formidable obstacles in implementing an approach that prioritizes focus on form rather than focus on forms. These problems are now well documented (see, for example Carless, 2004) and cannot be easily overcome.

Perhaps, though, as I have argued, it is time to stop treating FonF and FonFs as approaches and instead view focus on form as a set of procedures for attracting attention to form while learners are engaged in meaning making. Such procedures belong naturally to task-based teaching but they can also be found in more traditional approaches providing there is some opportunity for free production in the L2. There are current studies (e.g. Cintron-Valentin and Ellis, 2015) that claim to investigate 'focus on form' but also include explicit instruction of a target feature prior to the focus on form activity. We urgently need studies that compare 
focus on form treatments that include and exclude explicit instruction with care taken to measure the effects on the acquisition of both explicit and implicit knowledge. Only with such studies will we be able to move on from simplistic comparisons of FonF and FonFs as approaches and the futile debates about which is superior.

\section{Notes}

1. In fact it is doubtful whether any instructional approach is totally devoid of a focus on form. In immersion classrooms, for example, corrective feedback of various kinds still occurs (Lyster \& Ranta, 1997).

2. Post-task activities can also involve focus on form activities as, for example, when learners are asked to present a report of the outcome of the task they have just completed. Post-task activities can also be of the focus on forms kind (e.g. grammar exercises).

3. Sheen (2006) found that uptake-with-repair was more likely following corrective feedback in a Korean-as-a- foreign-language context than in the immersion classrooms investigated by Lyster and Ranta (1997).

4. Corrective feedback also occurs in focus on forms. My concern here, however, is with corrective feedback as a type of focus on form.

5. Of these meta-analyses only Lyster \& Saito (2010) focuses exclusively on classroombased studies of corrective feedback. The other meta-analyses also included laboratory-based studies.

\section{References}

Adams, R. (2007). Do second language learners benefit from interacting with each other? In A. Mackey (ed.). Conversational Interaction in Second Language Learning (pp29-51). Oxford: Oxford University Press.

Aljaafreh, A. and J. Lantolf. (1994). Negative feedback as regulation and second language learning in the Zone of Proximal Development. The Modern Language Journal 78: 465-83.

Bax, S. (2003). The end of CLT: A context approach to language teaching. ELT Journal 57: 278-287.

Bygate, M. (1996). Effects of task repetition: appraising the developing language of learners. In D, Willis and J. Willis (eds.). Challenge and Change in Language Teaching. Oxford: Heinemann.

Bygate, M. (2001). Effects of task repetition on the structure and control of oral language. In M. Bygate, P. Skehan, and M. Swain (eds.): Researching Pedagogic Tasks, Second Language Learning, Teaching and Testing. Harlow: Longman.

Carless, D. (2004). Issues in Teachers' Reinterpretation of a Task-Based Innovation in Primary Schools. TESOL Quarterly, 38(4), 639-662.

Chaudron, C. (1977). A descriptive model of discourse in the corrective treatment of learners' errors. Language Learning, 27, 29-46. 
Cintron-Valentin, M. and Ellis, N. (2015). Exploring the interface: Explicit focus-on-form and learned attentional biases in L2 Latin. Studies in Second Language Acquisition 37, 197235.

DeKeyser, R. (1998). Beyond focus on form: cognitive perspectives on learning and practicing second language grammar. In C. Doughty and J. Williams (eds.). Focus on Form in Classroom Second Language Acquisition. Cambridge: Cambridge University Press.

Doughty, C. (2001). Cognitive underpinnings of focus on form. In P. Robinson (ed). Cognition and Second language Instruction. Cambridge: Cambridge University Press.

Doughty, C. and Varela, E. (1998). Communicative focus-on-form. In C. Doughty and J. Williams (eds.). Focus-on-form in Classroom Second Language Acquisition pp. 114-138). Cambridge: Cambridge University Press.

Doughty, C. and J. Williams (eds.). (1998a). Focus-on-form in Classroom Second Language Acquisition. Cambridge: Cambridge University Press.

Doughty, C. and Williams, J. (1998b). Issues and terminology. In C. Doughty, C. and J. Williams (eds.) pp. 1-11).

Doughty, C. and Williams, J. (1998c). Pedagogical choices in focus on form.In Doughty, C. and J. Williams (eds. Pp. 197-261.

Ellis, R. (2003). Task-based language learning and teaching. Oxford: Oxford University Press.

Ellis, R. (2005). (Ed.). Planning and Task Performance in a Second Language. Amsterdam: John Benjamins Publishing Company.

Ellis, R. (2009a). Task-based language teaching: Sorting out the misunderstandings. International Journal of Applied Linguistics, 19(3), 221-246.

Ellis, R. (2009b). The differential effects of three types of planning on fluency, complexity and accuracy in L2 oral production. Applied Linguistics 30, 474-509.

Ellis, R. (2012). Second Language Classroom Research and Language Pedagogy. Malden, USA: Wiley-Blackwell.

Ellis, R. (2015). Understanding Second Language Acquisition: $2^{\text {nd }}$ Edition. Oxford: Oxford University Press.

Ellis, R., H. Basturkmen, and S. Loewen. (2001). Learner uptake in communicative ESL lessons. Language Learning 51: 281-318.

Ellis, R., Basturkmen, H., \& Loewen, S. (2002). Doing focus on form. System, 30, 419-432.

Ellis, R., S. Loewen, and R. Erlam. (2006). Implicit and explicit corrective feedback and the acquisition of L2 grammar. Studies in Second Language Acquisition 28: 339-68. 
Ellis, R. and Sheen, Y. (2006). Re-examining the role of recasts in SLA. Studies in Second Language Acquisition 28: 575-600.

Fotos, S. (1998). Shifting the focus from forms to form in the EFL classroom. ELTJ 52: 301307

Goo, J. and A. Mackey. (2013). The case against the case against recasts. Studies in Second Language Acquisition 35: 127-65.

Kartchava, E. and Ammar, A. (2014). The noticeability and effectiveness of corrective feedback in relation to target type. Language Teaching Research 18, 428-452

Lee, S. and H. Huang. (2008). Visual input enhancement and grammar learning. A metaanalytic review. Studies in Second Language Acquisition 30: 307-31.

Levelt, W.J. (1989). Speaking: From intention to articulation. Cambridge: Cambridge University Press.

Li, S. (2010). The effectiveness of corrective feedback in SLA: a meta-analysis. Language Learning, 60: 309-65.

Littlewood, W. (2007). Communicative and task-based language teaching in East Asian classrooms. Language Teaching 40, 243-249.

Littlewood, W. 2014. Communication-oriented teaching: Where are we now? Where do we go from here? Language Teaching 47, 249-362.

Loewen, S. (2003). Variation in the frequency and focus of incidental focus on form. Language Teaching Research, 7: 315-345.

Loewen, S. (2005). Incidental Focus on Form and Second Language Learning. Studies in Second Language Acquisition, 27, 361-86.

Loewen, S., and J. Philp. (2006). Recasts in the adult English L2 classroom; Characteristics, explicitness, and effectiveness. Modern Language Journal, 90, 536-56.

Long, M. (1983). Native speaker/non-native speaker conversation in the second language classroom.” In M. Clarke and J. Handscombe (eds.). On TESOL '82. Washington D.C.: TESOL.

Long, M. (1988). Instructed interlanguage development. In L. Beebe (ed.). Issues in Second Language Acquisition: Multiple Perspectives. Rowley, Mass: Newbury House (pp. 115-141).

Long, M. 1991. Focus on form: a design feature in language teaching methodology. In K. de Bot, R. Ginsberg, and C. Kramsch (eds.): Foreign Language Research in Cross-cultural Perspective. Amsterdam: John Benjamins.

Long, M. (1996). The role of the linguistic environment in second language acquisition. In W. Ritchie and T. Bhatia (eds.). Handbook of Second Language Acquisition. San Diego: Academic Press. 
Long, M. (1997). Focus on form in task-based teaching. McGraw Hill. Available at http://change.c4835149.myzen.co.uk/wp-content/uploads/2013/12/Focus-on-form-in-TaskBased-teaching.pdf

Long, M. (2006). Problems in SLA. Mahwah, N.J.: Lawrence Erlbaum.

Long, M. (2015). Second Language Acquisition and Task-based Language Teaching. Malden, MA: Wiley Blackwell.

Long, M., and G. Crookes. (1992). Three approaches to task-based syllabus design. TESOL Quarterly, 26: 27-56.

Lynch, T. \& MacLean, J. (2000). Exploring the benefits of task repetition and recycling for classroom language learning. Language Teaching Research 4, 221-250.

Lyster, R. (2001). Negotiation of form, recasts, and explicit correction in relation to error types and learner repair in immersion classrooms. Language Learning, 51 (Suppl. 1), 265-301

Lyster, R. (2004). Differential effects of prompts and recasts in form-focused instruction. Studies in Second Language Acquisition, 26, no.3: 399-432.

Lyster, R., and L. Ranta. (1997). Corrective feedback and learner uptake: Negotiation of form in communicative classrooms." Studies in Second Language Acquisition, 19, 37-66.

Lyster, R., and K. Saito. (2010). Oral feedback in classroom SLA: A meta-analysis." Studies in Second Language Acquisition, 32, 265-302.

Lyster, R., Saito, K., \& Sato, M. (2013). Oral corrective feedback in second language classrooms. Language Teaching, 46 (1), 1-40.

Mackey, A. (2006). Feedback, noticing and instructed second language learning. Applied Linguistics 27, 405-30.

Mackey, A. and J. Goo. (2007). Interaction research in SLA: a meta-analysis and research synthesis. In A. Mackey (ed.): Conversational Interaction in Second Language Acquisition: A Collection of Empirical Studies. Oxford: Oxford University Press.

McDonough, K. (2004). Learner-learner interaction during pair and small group activities in a Thai EFL context. System, 32: 2007-34.

Mochizuki, N. and Ortega, L. (2008). Balancing communication and grammar in beginninglevel foreign language classrooms: A study of guided planning and relativization. Language Teaching Research 12:,11-37.

Nakatsukasa, K. and Loewen, L. 2015. A teacher' first language use in form-focused episodes in Spanish as a foreign language classroom. Language Teaching Research 19, 133149. 
Nassaji, H. (2010). The occurrence and effectiveness of spontaneous focus on form in adult ESL classrooms. Canadian Modern Language Review, 66, 907-933.

Nassaji, H. (2011). Immediate learner repair and its relationship with learning targeted forms in dyadic interaction. System, 39, 17-29.

Nassaji, H. (2013). Participation structure and incidental focus on form in adult EFL classrooms. Language Learning, 63, 835-869.

Nassaji, H., \& Fotos, S. (2010). Teaching grammar in second language classrooms: Integrating form-focused instruction in communicative context. London: Routledge.

Nicholas, H., P. Lightbown, and N. Spada. 2001. Recasts as feedback to language learners. Language Learning, 51, 719-58.

Ortega, L. (1999). Planning and focus on form in L2 oral performance. Studies in Second Language Acquisition, 21, 109-148.

Ortega, L. (2005). What do learners plan? Learner-driven attention to form during pre-task planning. In R. Ellis (Ed.). Planning and task performance in a second language. (pp. 77109). Amsterdam: John Benjamins.

Pang, F., \& Skehan, P. (2014). Self-reported planning behaviour and second language performance in narrative retelling. In Skehan P. (Ed.). pp. 95-128.

Pica, T. (1992). The textual outcomes of native speaker-non-native speaker negotiation: what do they reveal about second language learning. In C. Kramsch and S. McConnell-Ginet (eds.): Text and Context: Cross-disciplinary Perspectives on Language Study. Lexington, Mass.: D.C. Heath and Company.

Prabhu, N.S. (1987). Second Language Pedagogy. Oxford: Oxford University Press.

Révész, A. (2012). Working memory and the observed effectiveness of recasts on different L2 outcome measures. Language Learning 62: 93-132.

Russell, J., and N. Spada. (2006). The effectiveness of corrective feedback for the acquisition of L2 Grammar: A meta-Analysis of the rsearch.” In J. Norris and L. Ortega (eds.) Synthesizing Research on Language Learning and Teaching. Amsterdam: John Benjamins.

Schmidt, R. (1994). Deconstructing consciousness in search of useful definitions for applied linguistics. AILA Review 11, 11-26.

Schmidt, R. (2001). Attention. In P. Robinson (ed.). Cognition and Second Language Instruction. Cambridge: Cambridge University Press.

Sheen, R. (1994). A critical analysis of the advocacy of the task-based syllabus. TESOL Quarterly, 28(1), 127-151.

Sheen, R. (2003). Focus on form-a myth in the making? ELT journal 57(3), 225-233. 
Sheen, R. (2006). Focus on forms as a means of improving accurate oral production. In A. Housen and M. Pierrard (eds): Investigations in Instructed Second language Acquisition. Berlin: Mouton de Gruyter.

Sheen, Y. (2004). Corrective feedback and learner uptake in communicative classrooms across instructional settings. Language Teaching Research, 8, 263-300.

Sheen, Y. (2006). Exploring the relationship between characteristics of recasts and learner uptake. Language Teaching Research, 10, 361-392.

Sheppard, C. (2006). The effects of instruction directed at the gaps second language learners noticed in their oral production. Unpublished PhD thesis, University of Auckland.

Shintani, N. (2015). The Incidental Grammar Acquisition in Focus on Form and Focus on Forms Instruction for Young Beginner Learners. TESOL Quarterly, 49 (1), 115-140.

Shook, D. (1999). What foreign language reading recalls reveal about the input-to-intake phenomenon. Applied Language Learning 10: 39-76.

Skehan, P. (1996). A framework for the implementation of task-based instruction. Applied Linguistics 17, 38-62.

Skehan, P. (1998). A Cognitive Approach to Language Learning. Oxford: Oxford University Press

Skehan, P. (2009). Modelling Second Language Performance: Integrating complexity, accuracy, fluency and lexis. Applied Linguistics, 30, 4, 510-532.

Skehan P. (2015). (ed.). Processing Perspectives on Task Performance, Amsterdam: John Benjamins.

Storch, N., and G. Wigglesworth. (200. Is there a role for the use of the L1 in an L2 setting? TESOL Quarterly, 37, 760-770.

Swain, M. (1998). Focus on form through conscious reflection. In C. Doughty and J. Williams (eds.). Focus-on-form in Classroom Second Language Acquisition. Cambridge: Cambridge University Press.

Swan, M. (2005). Legislation by hypothesis: The case of task-based instruction. Applied Linguistics 26(3), 376-401.

Tomlin, R. and V. Villa. 1994. Attention in cognitive science and second language acquisition. Studies in Second Language Acquisition 16: 183-203.

Van den Branden, K. (ed.). (2006). Task-based Language Education: From theory to Practice. Cambridge: Cambridge University Press.

VanPatten, B. (1990). Attending to form and content in the input. Studies in Second Language Acquisition 12: 287-301. 
VanPatten, B. (1996). Input Processing and Grammar Instruction in Second Language Acquisition. Norwood, N.J.: Ablex.

Wen, Z. (2015). Working memory in second language acquisition and processing: The phonological/executive model. In Z. Wen, M. Mota and A McNeill (eds). Working Memory in Second Language Acquisition and Processing (pp. 41-62). Bristol: Multilingual Matters.

Williams, Jessica. (2001). The effectiveness of spontaneous attention to form. System 29, 325-340.

Williams, John. (2009). Implicit learning in second language acquisition. In W. Ritchie and T. Bhatia (eds). The New Handbook of Second Language Acquisition (pp. 319-344). Bingley, UK: Emerald Publishing. 